\title{
Exploring the Product Diversification for Sustainable Tourism Development: The Case of Al-Baha Region, KSA
}

\author{
SAMI MENSI \\ Associate Professor, College of Business Administration, Al-Baha University, KSA \\ E-mail: salmansi@bu.edu.sa \\ MOHAMMED ALI ZARAI \\ Associate Professor, College of Business Administration, Al-Baha University, KSA \\ E-mail: mzarai@edu.bu.sa
}

\begin{abstract}
Bearing on the need to promote the tourism industry, this study examines tourism activities in Al-Baha region. The aim is to examine the factors and determinants of promoting tourism in this region. The studied region enjoys a panoply of natural and human resources and tourism potential, in addition to natural sceneries, parks, various wild animals, plantations, monuments, museums and ancient and unique urban patterns. Moreover, the region is known by an infrastructure that promotes its competitive edge against mountain-close tourist regions in the kingdom. Our methodology is a case study that aims at exploring the specificities and components of tourism activities in the region. The results indicate that the tourism services offered in Al-Baha region are acceptable and close to good. Their prices are acceptable; however, those of accommodations are found to be high and even expensive. The study then recommends the promotion of complementary specific and mid-range services. Special focus should be given to popular media channels as efficient channels to reach wider population segments. Moreover, authorities should develop coastal tourism in line with demand to maintain quality of services. They should also promote market studies to determine outside markets and their needs and promote, diversify and market publicly tourism products, increase accommodation capacity and services in regions that are the focus of local and domestic interest. Moreover, there is an urgent need to focus on training the labor force on delivering tourism services and setting up specific training programs like specialized schools and universities.
\end{abstract}

Keywords: Product Diversification, Sustainable Tourism, Al-Baha Region.

\section{Introduction}

Tourism is considered to be a domestic pillar for any modern country, not only for economic growth but also for several other components, like promoting local culture and employment and presenting the nation's culture and its heritage to others. Developed countries focus on both the local and external tourist while putting down their strategic tourism plans. Weather and climate conditions no longer determine the success of one region or others. Tourism has become an industry, a science and a service and those who master it certainly will succeed. With the expansion of this industry and its services and as a contributor to GDP for some countries, awareness about its potential has grown and tourism media started marketing tourism services by organizing tourism festivals, shows, fairs, programs and ads.

Recently, tourism has witnessed a boost, in particular ecotourism that values nature and the environment. In addition to traditional residential tourists, new customers emerged who favor getting away from the city's hustle and enjoy the beauty and purity of nature and its rich sceneries and wild life and its related local habitants and their culture, modern and ancient alike. 
The Kingdom of Saudi Arabia is one of the countries that recorded positive and encouraging tourism figures and this in few years. Such figures result from the government's interest in promoting tourism because of its importance in boosting economic growth. The government's interest is acknowledged in its setting up a higher commission supervising tourism and monuments, called the supreme commission of tourism and antiquities. The commission uses exclusively media to promote internal tourism ${ }^{1 .}$

Promoting tourism industry in KSA shows a slow progress because of lack of official and popular interest. Tourism has become a fully-fledged industry and service provider in which the joint official and popular efforts are crucial for its promotion. However, there are many other intertwined factors that may affect promoting the tourism industry.

Although Al-Baha region enjoys natural tourism resources, there are obstacles facing its promotion. Tourism has become an industry that serves a wide range of customers. The region's tourism potential needs development and promotion. Since tourism needs raising awareness about its ecological and tourism dimensions, this study tries to highlight some important factors that affect attracting tourists and those interested in promoting the region's heritage and its tourism services.

The methodology we adopted is the case study technique. This technique consists in collecting a large and a comprehensive body of data about a unique case or a limited number of cases. The aim is to reach a deep understanding of the studied construct and similar phenomenon. This methodology rests on collecting data about the studied phenomenon, its past and its relationships for a deep and a better understanding of the community represented by the phenomenon.

The present paper is structured into six sections. The second section presents the literature review. The third section presents Al-Baha region specifications. The fourth section explores the tourism product diversification in AlBaha region. Section five presents the potential and obstacles for Sustainable Tourism Development in Al-Baha Region. Finally, section six provides the conclusions and recommendations.

\section{Literature Review}

The process of tourism development starts by listing and scientifically evaluating the sources that can be used in the tourism industry, and even find new areas that attract tourists such as tourist villages or tourismoriented areas. Evaluation here is not just a theoretical endeavor, but a comparative evaluation of competitors' tourism products and their dependence on international tourism trends and demand, which are the basis for identifying and creating the infrastructure of domestic tourism. This can be made by encouraging tourism investment and facilitating the work of investment companies by reducing taxes and customs procedures on equipment necessary for their projects ${ }^{2}$. Al-Qahtani, Arbab and Ibrahim (1997) focused on tourism in the Assir region in Saudi Arabia. The geographical approach that reflects the tourist personality of the place was used. It determines the type of tourist activity, its weight, its location and its interaction with others through its natural and human dimensions. The approach focuses on natural attractions such as sites, natural plants, topography and cultural attractions such as parks, types of traditional architecture and tourist facilities such as roads, water, health and electrical services, and tourist services such as accommodation, food, markets, banking services and the needs and constraints of tourism development in the area. The study concludes by defining the features of a strategic plan for tourism development in the region in terms of tourism volume demand, tourism dimensions and its territorial scope, tourism awareness, the importance of tourism media and marketing and the establishment of regional museums. The aim of the Abha Chamber of Commerce and Industry's working paper on the elements and

\footnotetext{
${ }^{1}$ Higher Commission for Tourism and Antiquities, 2002 Report, Tourism Statistics for the founding period, Riyadh.

2 Toufik Maher AbdelAziz, Tourism Industry, Wahren Publishers, Oman, p. 198.
} 
obstacles of tourism development in Assir $(1998)^{3}$ was to activate tourist dimensions and face the obstacles to tourism development in the Asir region. It examined the most important natural and human attractions such as the climate, highlands and plains overlooking the Red Sea and historical monuments. The recommendations included the development of the role of the Tourism Development Committee so as to take in charge the development of tourism in Assir and the need to develop and renew the infrastructure of the Asir region like the maintenance of the road network and the presence of a party responsible for tourism investment, which provides investment opportunities to investors. The results of this working paper indicates that motivation makes workers and people feel internally eager to satisfy their functional needs, as well as it feeds the internal feeling that directs their behavior to meet a particular unsatisfied need.

The study of Yasser Ali Al-Shihri (1993) ${ }^{4}$ aimed at examining published tourism media in KSA and its role in promoting internal tourism in the country. The author focused on the topics about internal tourism published in the Saudi daily newspapers Riyadh, Okaz and Al-Yawm (Today). The author focused also on the printed media publications of tourism promotion committees, in terms of the content provided and the extent to which the public uses it. He also reviewed the extent to which the Saudi press has taken care of internal tourism by looking into the quantity and nature of its publications on internal tourism. He also examined the extent to which the targeted audience uses newspaper articles on internal tourism published in the Saudi daily newspapers and their use of media materials published by the tourism promotion committees. The study of Nasreen Ennabawi $(1993)^{5}$ examined the demand function of internal tourism in Jeddah and identified the most important variables that can affect that demand, highlighting the most influential. The study concluded that the most important means to promote tourism is to spread tourism awareness among tourists, tourism officials and citizens through publicity, media and bulletins.

The study confirmed that tourism publicity, defined as "broadcasting selected tourism proposals to the minds of members of the selected public through the use of communication means, in order to promote and stimulate tourism mobility into the country", has a key role in promoting tourism mobility as it raises tourism awareness. The study of Noura Halafy $(2010)^{6}$ aimed at determining the natural and human tourism dimensions in Al-Namas governorate, their spatial distribution, studying the demographic, social and economic characteristics of tourists, and their satisfaction with tourism in Al-Namas Governorate. The results concluded that tourism resources in Namas governorate are not that important and that the Namas governorate has favorable natural and human resources and tourism potential. Similarly, tourism activities in the province of Namas is a family tourism resort, targeted exclusively to "government employees".

Al-Baha is one of the thirteen administrative regions of the Kingdom of Saudi Arabia. It was founded as an administrative area in May in 1964. It is located in the southwestern part of the Arabian Peninsula on the Sirat mountain chains, named by El Cherif the Hijaz garden and it used to be called Makkah Farm ${ }^{7}$.

\section{Al-Baha Region Specifications}

$\mathrm{Al} \mathrm{Baha}$ is the smallest region in the Kingdom of Saudi Arabia with an area of $10362 \mathrm{~km} 2$. Al Baha is its largest city, and its population is distributed across about 1200 villages. The region is known by its terraces,

${ }^{3}$ Chamber of Commerce and Industry of Abha, 1999 : A Working Paper on the factors and obstacles of Tourism development in Assir, Division of Economic and studies and research. Abha.

4 Al-Shahri Yasser, Media of Domestic Tourism in Jeddah city. MA Dissertation, University of King Abdel Aziz, Jeddah, 1993.

${ }^{5}$ Al-Nabawi Nessrine Issmaiel, Assessment of Tourism Demand in Jeddah. MA Dissertation University of King Abdel Aziz, Jeddah, 1993.

${ }^{6}$ Bent Gharm Allah Noura Mohamed Al Hamoud Alhalafy : Factors attracting tourism in the province of Namas from the point of view of tourists, MA Dissertation, University of King Abdel Aziz, Geography Department, 2010.

${ }^{7}$ Sustainable tourism plan, tourism development strategy of Al-Baha region, p19. 
parks and forests, where natural vegetation is varied. It also promises many views of the slopes, with archeological monuments and places. The population of Al-Baha region is 411888 people, including 63252 non-Saudis and 348,636 Saudis, according to the latest census of 2010. As for the indigenous people, half of them live in the region and the other half are outside. They are distributed cross the following governorates: Baha and its suburbs Ghamed and Zahran Al-Sarat, Baljarshi and its suburbs: Ghamed AlSarra, Al-Mundaq and its dependencies, Em Mundaq and its dependencies, Zahran Al-Sarat, El Makhwat and its dependencies, Zahran and Ghamed Tihama, El Qilwa and its dependencies Qura and its dependencies, Zahran Al-Sarat, Al-Aqiq and its dependencies: Gamad Al-Badia, Ghamed Ezzenned and El Hajra $^{8}$.

The Sarwat Mountains dominate the region, which extend from the north-west to the south-east. Most of the towns and the villages of the region are located 20,000 meters above sea level. Its three distinct features are the coast, the mountainous and the desert. With no direct coastal strip, the lowland at the bottom of the Sarwat Mountains is hot and humid, with an average temperature of 30 degrees Celsius and an average rainfall of $150 \mathrm{~mm}$ per year. The temperature in the central mountainous region is $17^{\circ} \mathrm{C}$ and average precipitation is $500 \mathrm{~mm}$.

As the mountains gradually descended towards the desert to the east, the temperature rises and the area became drier. The average temperature is $22^{\circ} \mathrm{C}$ and the average rainfall rate is $15 \mathrm{~mm}^{9}$

Generally, the region enjoys a mild mountain climate in the summer and is cool in the winter, dense forests and can develop agriculture in the rivers where seasonal water is available.

Al Baha has several infrastructure services in terms of four main diverse water sources. Water and sewerage systems, pipes and treatment plants have been set up. Focus is put on improving the service provided to customers. Old projects have been developed. Water and sewerage infrastructure projects have been established in the cities of Al-Baha, Baljarshi, Al-Aqiq, Al-Makhwat, Al-Qalwa, Al-Mundaq and AlQura.

Al-Baha is linked with its villages and other parts of the Kingdom with a modern and an operational road network. This has played a prominent role in achieving development plans and facilitating mobility for education, trade and tourism. One of the most important roads that reach Al-Baha is the 47-kilometer-long Al-Baha road. It connects Tuhama and Al-Sarat regions with 26 tunnels and 64 bridges. It facilitated communication between the two regions and increased exchange of products. It linked Al-Baha to the coastal road of Jeddah-Jizan, Al-Aqiq, Jarab (92 km), Al-Hajra (108 km), Taif Road, Abha, Jazan (753 $\mathrm{km}$ ). This road is considered one of the largest road projects in the Kingdom, which links three regions starting from Taif to the south, the Taif road, Al-Baha, known as the tourist road, Mecca road, Jazan known as the coastal road. Al Baha Airport is located $36 \mathrm{~km}$ from the city of Al-Aqiq.

Education services reach all villages, suburbs, cities, governorates, rivers and valleys. The city also has primary, middle and secondary schools, Koranic schools, private schools, scientific institutions, vocational institutions, business institutions, technical colleges, health colleges, the community college of Umm AlQura University, Al-Baha University for boys and girls, founded in 2007. There is also an international scientific university, Al-Baha University.

The Al-Baha city hosts the King Fahad Central Hospital, which is one of the reference hospitals in the region (it is scheduled to be converted to a specialized hospital). There is also a rehabilitation center in addition to a number of hospitals and health centers spread throughout the region. The biggest is the new Beljarshi Hospital, Al-Qura General Hospital and Al-Mundaq General Hospital, a new building is currently

${ }^{8}$ The previous reference http://www.mob.gov.sa/about albaha region.php

${ }^{9}$ Mohamed Ahmad Mohamed AbdelAl, urban development of al-Baha city, p25. 
being built in Al-Mundaq, Beljarshi Ghadran Hospital, Al-Aqiq General Hospital, and the new Makhawat Hospital.

\section{The Tourism Product Diversification in Al-Baha Region.}

There are a number of indicators that represent tourism status in the region. In 2013, tourism-generated revenues amounted to about one billion riyals, about $65 \%$ of GDP of the same year. The number of employees in this sector reached about 300 thousand workers during the same year, representing $4.9 \%$ of the total number of workers in the Kingdom. Despite this figure, the tourism sector in Al-Baha is one of the most promising sectors for the national economy. There are still many tourism dimensions awaiting Saudi investors to support their development.

It is worth mentioning that success in attracting Saudi tourists to spend their holidays in the area will lead to reallocating interesting amounts of money into the geographical boundaries of the Kingdom and reduce leakage of national income.

Al-Baha is expected to secure a greater share of domestic and regional tourism over the next few years as the region has a number of tourist attractions. Moreover, tourism is increasingly attracting interest of domestic stakeholders. Under new regulations, especially with the incentives and encouragements that came along the establishment of the Supreme Commission for Tourism, it is likely that demand for tourist activities in Al-Baha will increase in the coming years.

In the summer of 2013, accommodation in hotels and furnished units in Al-Baha reached high occupancy rates, almost $100 \%$. These high rates reflect the large number of visitors and holidaymakers who visited the region and it is expected to reach one and a half million tourists by the end of the season, according to the Chairman of the Supreme Supervisory Committee organizing Al-Baha summer festival.

In recent years, the tourism sector in Al-Baha has witnessed the creation of new classified accommodation units while old ones have been improved. Currently, the committee operates 8 hotels, 210 furnished apartments with a total of over 2,400 units and seven tourist resorts.

Table 1: Some Tourism Indicators from AlBaha Region

\begin{tabular}{|c|c|c|c|}
\hline Tourism Indicator & $\mathbf{2 0 1 2}$ & $\mathbf{2 0 1 5}$ & $\mathbf{2 0 2 0}$ (expected) \\
\hline Tourism share in GDP & $6.8 \%$ & $8.9 \%$ & \% 11 \\
\hline Tourism added value & 70.2 Billion riyals & 77.3 Billion riyal & Billion riyal 107 \\
\hline $\begin{array}{c}\text { Net tourism share in GDP } \\
\text { (oil income excluded) }\end{array}$ & $7.2 \%$ & $7.9 \%$ & million jobs 1.8 \\
\hline $\begin{array}{c}\text { Direct employment } \\
\text { opportunities }\end{array}$ & 1.3 million jobs & 1.5 million jobs & million jobs 1.8 \\
\hline $\begin{array}{c}\text { Total number of jobs in the } \\
\text { sector (direct and indirect) }\end{array}$ & 709.000 jobs & 1.262 million jobs & million trips 1.774 \\
\hline Local trips & 22.5 million trips & 68.4 million trips & Billion riyals 64.9 \\
\hline Expenditure on local trips & 32.6 Billion riyals & 45.9 Billion riyals & Billion riyal 200 \\
\hline In-bound trips & 49 Billion riyal & 98.4 Billion riyal & thousand rooms 2071 \\
\hline $\begin{array}{c}\text { Expenditure on in-bound } \\
\text { trips }\end{array}$ & $\begin{array}{c}157.430 \text { (authorized } \\
\text { according to the new } \\
\text { classification) }\end{array}$ & $\begin{array}{c}197 \text { thousand } \\
\text { rooms }\end{array}$ & thousand apartments 147 \\
\hline $\begin{array}{c}\text { Number of hotel rooms } \\
\text { (68.3\%) }\end{array}$ & $\begin{array}{c}\text { Occupancy rate } \\
\text { apartments }\end{array}$ & \\
\hline
\end{tabular}

The relevant authorities in the region annually follow up and monitor these units to determine their suitability for housing and to adjust prices in accordance with the regulations, complying with the 
directives of the Governor of Al-Baha Region. The aim is to revive tourist and leisure facilities in the region.

Accommodation units in Al-Baha consist of furnished apartments, hotels, resorts, and motels. Their prices vary according to the committee's classification grid. Occupancy rates throughout the year reached $65 \%$ for hotels and about 54\% for furnished apartments, taking into account no price increases over the previous years. Compared to previous years, occupancy rates ranged between a minimum of $90 \%$ and $100 \%$. Visitors to the region came from 55 places from inside and outside the Kingdom.

During the summer festival, the percentage of those who stayed in hotel rooms and furnished apartments is more than $52 \%$, while about $21 \%$ stayed in their own housing units ${ }^{10}$.

The results of the survey showed that $68 \%$ of the studied sample came to the region for recreation and tourism, while visitors attending the festival were approximately $14 \%$, while the average number of nights spent was about four nights, one costs about 371 Saudi riyals.

Hotels: The number of starred hotels in Al-Baha is 11 hotels representing $0.7 \%$ of the total starred hotels in the Kingdom.

Table 2: The starred hotels in Al-Baha Region

\begin{tabular}{|c|c|c|c|c|c|}
\hline Total number of rooms & The minimum 2 stars & 3stars & 4stars & 5stars & Total \\
\hline 296 & 2 & 5 & 4 & 0 & 11 \\
\hline
\end{tabular}

Furnished Housing Units: The number of licensed furnished housing units in Al-Baha is (47) units, representing $2.35 \%$ of the total furnished units in the Kingdom.

Table 3: The furnished housing units in Al-Baha Region

\begin{tabular}{|c|c|c|c|}
\hline Region & Furnished units & Percentage & Total number of units \\
\hline Al-Baha & 59 & $3 \%$ & 2.207 \\
\hline
\end{tabular}

Despite lack of accommodation units for such a large number of visitors, Al-Baha remains one of the most important tourist destinations in the Kingdom and the Gulf. It hosts a wide range of programs and events targeting all community segments in its annual festival, in addition to the abundance of forests, landscapes and mild temperate, and the archaeological sites and villages that attract tourists year after year ${ }^{11}$.

Table 4: The number of visitors in Al-Baha Region

\begin{tabular}{|c|c|c|c|c|c|}
\hline Al-Baha & Hotels & Private units & Furnished units & Other & Total \\
\hline Number of visitors & 32.368 & 365.138 & 119.707 & 158.752 & 676.965 \\
\hline Percentage & 5 & 54 & 18 & 23 & 100 \\
\hline
\end{tabular}

The average length of stay for local trips in Al-Baha is about 4-6 days. The mode of transport used for tourist trips to Al-Baha in 2011 was $(5 \%)$ by air, and about $(95 \%)$ by land. Private units in Al-Baha ranked first by $54 \%$, residential units by $18 \%$, and hotels accounted for $5 \%$ of total local tourism trips to the region.

Marketing and trade exhibitions are one of the most important events for tourists in Al Baha region. They are organized in specific locations by the Tourism Promotion Committee of the region. Many international

10 Annual tourism report, Arab News newspaper, Sunday, March 2, issue number 87.

11 Department of licences and quality, MAS center, 2013, supreme commission for tourism and antiquities. 
and local companies, institutions and businesses participate throughout the summer. The exhibitions are very popular inside and outside the governorate. They are known by a large number of various and lowprice exhibits. Visitors and tourists are welcomed by gifts and served with what they need.

Sports activities are one of the most exciting summer activities for tourists in Al-Baha. They are considered to be the most important attractive events, especially for youth. Sports tourism allows visitors to practice various sports activities, especially those that require special abilities such as equestrian, trekking and hunting. Many tourists, especially the young, practice mountain climbing, which is highly becoming demanded and popular. This sport is likely to attract tourists to the region, as the geographical structure needed is available. The region is known for a plethora of mountains, with varying heights and degrees, allowing for using various skills by different age groups to enjoy the challenges of climbing, greenery and animal wildlife

Scientific or summer tourism is considered one of the most diversified tourist activities. They are held during the tourist season and attract both male and female youth. Summer schools are organized by the Ministry of Education in schools and government complexes, and offer many religious, cultural, recreational, social and scouting activities both inside and outside the province.

Poetry evenings in Al-Baha region are considered to be one of the most popular tourist programs for those fond of literature and poetry. They are held at Al-Baha literary club twice a week, following a specific schedule, where many writers and poets participate, both from inside and outside the province.

Al-Baha literary club is considered one of the cultural hubs in the Kingdom and is active locally and internationally. As for sports, there is a complete sports city (swimming, football, basketball, volleyball, other disciplines, accommodation, a restaurant, a mosque) and called King Saud Sports City.

\section{The Potential and Obstacles for Sustainable Tourism Development in Al-Baha Region}

Al-Baha has many tourist attractions, considered to be the driving forces for tourism development in this region. The most important of these factors are first the availability of a panoply of particular tourist patterns consisting of stunning views and forests, reservations, mountains and plains. Second comes security and safety for tourists and visitors. Next is the historical and cultural heritage of the region. Then, there is available infrastructure for roads, communication and electricity and other services. Then, there is the mild weather all year long. Prices are suitable for most of the tourists, as well as accommodation services are varied: hotels, furnished and private apartments, in addition to restaurants.

Moreover, the region has a number of advantages that can attract citizens to domestic tourism. This would reduce leakage of money and preserve national wealth. Equally important is to provide entertainment for young people and protect them from the dangers they may face when they travel abroad. Such an orientation may strengthen social ties and dissolve the differences between the people of the same homeland. It would contribute to the development of rural areas and reduce rural-urban migration as well as diversify national income sources.

These advantages and others are other driving forces for sustainable tourism development in Al-Baha region. They also need to be highlighted by media campaigns aimed at educating citizens about the advantages and potential of the region and the need to develop environmentally friendly behavior.

There are many obstacles facing the sustainable tourism development in Al-Baha. Among these obstacles, we mention: a) the small size of most tourist projects; b) the random distribution of leisure facilities and incomplete services in the same projects, c) similar and non-innovative tourist projects, d) lack of complete infrastructure in some areas (roads, drinking water, etc.). 
There is an urgent need to provide upscale hotel services to accommodate the increasing number of official and diplomatic delegations and senior guests of the region; Princes and Ministers, senior visitors and investors at various events held in Al-Baha. For instance, most of the ministers visited the region between 2012 and 2016. Also, the steady growth in the number of visitors from different regions of the Kingdom and the Gulf countries to enjoy the summer's mild weather. In addition, the increasing number and types of events (festivals, exhibitions, conferences, workshops, training courses) that are being held in the main institutions of the region (the Emirate, Universities, Chamber of Commerce).

Completing the necessary infrastructure and superstructure elements in Al-Baha area helps to increase the ability of the region to attract tourism investment projects. Increasing flights seating capacity in and out of Al-Baha as well as developing a direct double-lane network connecting the area with major cities. However, the major needs and requirements are that Al-Baha region needs high-end hotels and resorts to exploit the spectacular mountain landscape as well as rural guest houses and accommodation units. It needs about 450 additional hotel rooms and about 600 additional furnished housing units to meet the increasing demand of the coming years.

\section{Conclusions and Recommendations}

The study revealed that the region has many natural and human resources and a promising tourism potential represented by landscapes such as parks, land entertainment features, natural vegetation, and wildlife. There are also archaeological resources such as museums, old and unique urban patterns and various tourism programs. Moreover, infrastructure and superstructure are available in the region which contributed to the rise of tourism.

The study found that the level of offered tourist services in Al-Baha are good. The same is true about prices. Except for accommodation services, the level is high in general. This indicates that investment in tourism resources in the region is still at its beginning, evidenced by tourists' evaluation of the current level of tourist services.

The other findings that tested our research hypothesis is the visitors' needs in the region. The region has a number of resources and factors like the mild weather, and uncrowded leisure facilities. However, the obstacles relate essentially to the small tourism projects, random and unorganized distribution of leisure facilities and accommodation units, incomplete and distant services in the same project, similar projects and non-innovative new projects.

This makes it a strong competitor to the mountainous tourist cities in the Kingdom. It would provide security and safety for tourists and visitors. Encouraging tourism in the region, and promoting its historical and cultural heritage, and providing infrastructure for roads, telecommunication, electricity and other services are key recommendations. Moreover, there is mild weather most days of the year, prices are suitable for most tourists and the accommodation services are varied; hotels, furnished apartments and restaurants.

Such factors are considered to be driving forces for tourism development in Al-Baha region, if exploited properly. They should be the focus of media campaigns aimed at raising awareness of citizens and visitors about the importance of maintaining and preserving the natural resources and tourism potential of the region and maintain its sustainability.

Our recommendations highlight the importance of developing complementary specialized and intermediate services and the need to focus on mass media as effective communication channels in conveying tourism information to community members. It is recommended also to develop a balanced tourism offer, with the possibility of an increasing tourism demand, to maintain service quality. Conducting market studies in view of identifying external markets and developing, diversifying and marketing tourist products is another area 
that should be considered. Another area is increasing accommodation capacity and services in areas with high domestic and regional tourism demand. Moreover, there is an urgent need to train and promote a tourism service labor force and focus on relevant specialized programs by establishing tourism schools and universities.

Based on the findings of the study, the following recommendations can be proposed:

-Develop tourism promotion programs in Al-Baha region and fully exploit them for a satisfactory tourism product. These include natural resources which need to be highlighted by media, human resources, complementary services and cooperation with the University of Al-Baha and other colleges to study the feasibility of establishing a tourism college in the region, taking into account the possibility of developing or merging the existent colleges.

-The importance of developing complementary, specialized and intermediate services.

-The importance of statistics that need to be carefully documented and adopted by all studies.

-Develop balanced tourism offer, with the possibility of an increasing tourism demand, to maintain service quality.

-Conduct market and support studies in view of identifying foreign markets and their trends and develop, diversify and market tourism products.

-Increase accommodation capacity and services in areas with domestic and regional tourism demand and establish residential units in Al-Baha region.

-Expand air and land transport to support mobility within the Kingdom and to meet the expected inflow of tourists.

-There is a clear need for more efforts, which may be carried out by municipalities and employees in government and private institutions located in various tourist areas in Al-Baha region, despite a clear effort during the recent period.

-There is also an urgent need to organize and carry out intensive awareness-raising campaigns for citizens and tourists about the importance of following the tourism guide.

-Focus on the advantages and potential of tourism in the region, and market them in media campaigns in advance.

-Deal seriously with the disadvantages standing against the sustainable development of tourism and vegetation, and work to reduce environmental pollution through an integrated package of measures.

-Attracting seminars and conferences in the Kingdom, and in the Arab world is a significant move for the region that will further put it under the lights and make it an important tourist destination.

-Tourism labor force personnel should be reviewed and specialized and trained competencies should be reconsidered.

-Focus on training a labor force able to work in the field of tourism and set up specialized programs by establishing training institutes and specialized colleges.

-It is better to make people aware about the challenges facing the tourism sector, so that the best results can be achieved when investing in tourism and in order to reach the principle of sustainability. Educational programs should be implemented for this purpose.

-Further studies, research, and statistical surveys on the different tourism dimensions are needed to determine the type of obstacles, how to deal with them and to identify the best components necessary for sustainable tourism.

-Advertising festivals and national events as a means to attract tourists, and consider inviting known figures in the Kingdom. This is what the Emirate of the region and the relevant authorities are doing now.

-Supervise the level of performance of tourism services.

-We recommend that travel and tourism agencies prepare a variety of tourism programs outside the Kingdom linking the Hajj, Umrah, tourist facilities and the various elements of sustainable tourism. 


\section{Acknowledgments}

The authors acknowledge the financial support of the Deanship of Scientific Research at Al-Baha University, Kingdom of Saudi Arabia. This article, which is part of the research Project No. 44/1438, is developed within the framework of research Programs of Al-Baha University.

\section{References}

Abdessamii Sabri (1993), Theory of Tourism, second edition, AlToubji Inc Publishers, Cairo, 1993, p70

Al Atibi Abir Sourour (2002), Tourism and marketing in Kuwait, Vol 107, 2002, Wikipedia.

Al ghamdi Abdallah saad (1988), Urban centers in Al-Baha, unpublished PhD dissertation, University of Cairo, 1988, p122.

Al Haddad Abdelaziz marsh qahtan (2012), An economic analysis of honey production in Al-Baha, KSA, University of King Saud, Faculty of Food, 2012, p51.

Al Zouka Mohamed Khamiss (2015), Tourism Industry from a geography point of view, Dar A Maarifa, Alexandria 7, p13.

Al-Baha Newspaper : http://albahatoday.cc/news.php?action=showid=11458

Al-Nabawi Nessrine (1993), Assessment of Tourism Demand in Jeddah. MA Dissertation University of King Abdel Aziz, Jeddah, 1993.

Al-Qahtani Mohamed Shebli, Arbab Mohamed Ibrahim, AbdelMoneem Ali, (1997). Tourism, basics and definitions, A study of Assir Region in KSA, First Edition, Al-Medina Institue for Journalism and Publishing, Jeddah.

AlSajini Center for economic and management investment (1998), Importance of tourism, p.1, Volume of expected tourism demand in the kingdom, the third national tourism conference in the western region, $1998, \mathrm{p} 3$.

Al-Shebili Abderrahmen (1999), Media and Flags, Research and Studies of Media, 1999. Unknown Publisher.

AlTayar Nasser Aqil (2003), Impact of Tourism on KSA economies, pp. 64-218.

Belghanim Ibrahim (1998), Investment opportunities in entertainment and tourism in the western region, working paper, the third national tourism conference, the western region, 1998, p2.

Bent Gharm Allah Noura, Mohamed Al Hamoud Alhalafy (2010), Factors attracting tourism in the province of Namas from the point of view of tourists, MA Dissertation, University of King Abdel Aziz, Geography Department, 2010.

Bikri Suzanne (2008), Definition of the world tourism organization, 2008-2009, p80.

Center for Food and Farming Research (2006), environmental pollution and its impact on tourism development and vegetation in Al-Baha, KSA., University of King Saud, 2006, p19.

Chamber of Industry and Commerce (2002), Tourism market and tourism future horizons in the Kingdom, , a working paper of the chamber of industry and commerce of Jeddah, an introduction to the $14^{\text {th }}$ annual meeting of the saudi Econmic Association, 28-30 April, 2002, p804.

Dssouqi Sami (2002), international media cases and the previous reference, p175.

Essoukr Marwen (1999), Episodes from tourism economics, Jordan Majdalawi publishers, 1999, p17.

Gharam Allah (2001), Factors attracting tourism to the province of Namas from the tourist point of view, 2001, p29.

Gorowitz Madelaine (1993), Methods of Social Sciences, the Logic of Research, , translated by Rassem Ammar, the second book, 1993, Damascus, pp. 12-13.

Higher Commission for Tourism and Antiquities Report (2002), Tourism Statistics for the founding period, Riyadh.

Khadhran Bin Hamdan, AlHaj Ahmed AlHaj (2013), Tourism activity in KSA in the summer of 2013, Report of the Supreme commission for tourism and antiquities.

Saiid Salah Samira (1993), Factors attracting tourism in Jeddah, MA Dissertation, Geography Department, University of King Abdel Aziz, 1993. 
Supreme commission for tourism and antiquities (2011), Saudi urban heritage, diversity in unity, Riyadh, 2011, pp. 172-175.

Toufik Maher AbdelAziz (2010), Tourism Industry, Wahren Publishers, Oman, p. 198.

World Tourism Organization (1994), National and regional tourism planning, Methodologies and case studies, London B43. 